\title{
BACTERIA OF APIS MELLIFERA GASTROINTESTINAL TRACT: COUNTS, IDENTIFICATION AND THEIR ANTIBIOTIC RESISTANCE
}

\author{
Kačániová Miroslava ${ }^{1,2 *}$, Gasper Jaroslav , Brindza Ján ${ }^{3}$, \\ Schubertová Zuzana ${ }^{3}$, Ivanišová Eva ${ }^{4}$
}

\author{
${ }^{1}$ Department of Microbiology, Faculty of Biotechnology and Food sciences, \\ Slovak University of Agriculture, Nitra, Slovakia \\ ${ }^{2}$ Department of Bioenergetics and Food Analysis, Faculty of Biology and Agriculture, \\ University of Rzeszow, Poland \\ ${ }^{3}$ Department of Genetics and Plant Breeding, Slovak University of Agriculture, Nitra, Slovakia \\ ${ }^{4}$ Department of Storing and Processing Plant Products, Faculty of Biotechnology and Food Sciences, \\ Slovak University of Agriculture, Nitra, Slovakia
}

The aim of the present study was to identify of bacterial species inhabiting the intestinal tract of Apis mellifera L. Content on intestinal tract was cultured for isolation of Gram-negative and Gram-positive bacteria. Content of gut was streaked onto MacConkey agar which was incubated for $24-48 \mathrm{~h}$ at $37^{\circ} \mathrm{C}$ aerobically. For cultivation of Gram-positive and Gram-negative microflora, the inoculated Tryptone soya agar was incubated for $48-72 \mathrm{~h}$ at $30^{\circ} \mathrm{C}$. Then, the identification of isolates with MALDI-TOF MS Biotyper was done. After bacteria identification antibiotic resistance testing was done. Disc diffusion methods was applied and the following antibiotics discs were used: amikacin AMK $(10 \mu \mathrm{g})$, gentamicin GEN $(10 \mu \mathrm{g})$, tigecycline TGC $(10 \mu \mathrm{g})$ and chloramphenicol CM $(10 \mu \mathrm{g})$. Results show that the Gram-positive bacteria counts were from $2.17 \pm 0.04$ to $3.21 \pm 0.02 \mathrm{log}$ CFU/g and Gram-negative counts ranged from $2.36 \pm 0.14$ to $4.05 \pm 0.04 \mathrm{log} C F U / g$ in honey bee gut samples. Lactococcaceae, Micrococcaceae, Staphylococcaceae and Enterobacteriaceae were identified from Gram-positive and Gram-negative bacteria in bees gut. The Enterobacteriaceae were the most abundant and were represented with 8 bacterial species. The Gram-positive and Gram-negative bacterial species recovered exhibited the antimicrobial resistance to the antibiotics. Gram-positive and Gram-negative bacterial showed the more frequently resistance to tigecycline (9.5\%) and amikacin (8.2\%). The resistance to gentamycin (6.5\%) and chloramphenicol (4.1\%) was observed less frequently.

Keywords: Apis mellifera; Gram-positive and Gram-negative bacteria; antibiotic resistance

\section{Introduction}

Insects are the most diverse animal group on Earth, which evolutionary adapted to feed on a variety of substrates and matrices ranging from wood or phloem sap to blood. These nutritionally unbalanced diets are exploited and/or complemented with participation of microbiota insect. Insect microflora also played a major role in their adaptation and evolution (Rosenberg and Zilber-Rosenberg, 2011). Among the insects, the honeybees have great importance worldwide because of the pollination

\footnotetext{
*Corresponding author: Miroslava Kačániová, Department of Microbiology, Faculty of Biotechnology and Food sciences, Slovak University of Agriculture, Nitra, Slovakia, $\triangle$ Miroslava.Kacaniova@uniag.sk
} 
activity of crops, fruit and wild plants. The honeybees are essential for ecosystem and for a sustainable agriculture production. Microflora of honeybee is important for the bees community.

The microflora of gut could act actively against the bee pathogens and parasites, enhance bees immunity, and thus indirectly to increase the protection of honeybees' health (Evans and Lopez, 2004). Therefore, the studies on identification of the intestinal microflora of honey bees are needed. The aim of the present study was to estimate the counts of several specific groups of bacteria in the midgut and rectum of Apis mellifera with the detection of bacterial species and their antibiotic resistance.

\section{Materials and methodology}

Adult worker honey bees (Apis mellifera) were used for experiments. The worker honey bees were originated from the apiary from Middle Slovakia $(n=50)$ the specimens were obtained from the hive. The workers were decapitated and their midgut and rectum were removed and weighed to obtain a $0.1 \mathrm{~g}$ of gut content material.

Gram-positive and Gram-negative bacteria in bees gut were detected. Content of gut was streaked onto MacConkey agar (MCA, Merck, Germany) which was incubated for $24-48 \mathrm{~h}$ at $37^{\circ} \mathrm{C}$ aerobically. For cultivation of Gram-positive and Gram-negative microflora, the inoculated Tryptone soya agar (TSA, Oxoid) was incubated for $48-72 \mathrm{~h}$ at $30^{\circ} \mathrm{C}$.

Qualitative analysis of intestinal microflora was performed with MALDI-TOF Mass Spectrometry (Bruker Daltonics, Germany). Generated spectra were analyzed on MALDI-TOF Microflex LT (Bruker Daltonics) instrument using Flex Control 3.4 software and Biotyper Realtime Classification 3.1 with $\mathrm{BC}$ specific software. Criteria for reliable identification were a score of $\geq 2.0$ at species level and $\geq 1.7$ at genus level.

At least $100 \%$ of isolated bacterial strains of each bacterial species were used for antimicrobial susceptibility testing. A amount of $100 \mu \mathrm{l}$ of bacterial suspension in physiological solution with $0.5 \mathrm{McF}^{\circ}$ density was spread with sterile L-rods on the surface of Mueller Hinton agar (Oxoid, UK). Disc diffusion methods was applied and the following antibiotics discs (Oxoid, UK) were used: amikacin AMK $(10 \mu \mathrm{g})$, gentamicin GEN $(10 \mu \mathrm{g})$, tigecycline TGC $(10 \mu \mathrm{g})$ and chloramphenicol CM $(10 \mu \mathrm{g})$. Inoculated agars were incubated at $35 \pm 2{ }^{\circ} \mathrm{C}$ for $16-20 \mathrm{~h}$ according to the EUCAST (2013). Interpretation of inhibition zones were done in line with EUCAST (2015).

\section{Results and discussion}

Recent non-culture based investigations of the honey bee microbiome have focused on bees captured from within the hive, sampling either the entire alimentary tract, or only the midgut and hindgut (Mohr and Tebbe, 2006; Babendreier et al., 2007; Cox-Foster et al., 2007; Martinson et al., 2011; Disayathanoowat et al., 2011; Ahn et al., 2012; Moran et al., 2012; Sabree et al., 2012). Less attention has been paid to the microbial diversity of foraging bees, food stores and the pollination environment. Independent findings from solitary and social pollinators suggest that both potentially pathogenic and beneficial microbes are regularly vectored from the pollination environment or floral sources (Batra et al., 1973; Gilliam et al., 1989; Singh et al., 2010; McFrederick et al., 2012; 2013).

The Gram-positive bacteria counts were from $2.17 \pm 0.04$ to $3.21 \pm 0.02 \mathrm{log}$ CFU/g and Gram-negative counts ranged from $2.36 \pm 0.14$ to $4.05 \pm 0.04 \mathrm{log} C F U / g$ in honey bee gut samples. 
Lactococcaceae, Micrococcaceae, Staphylococcaceae and Enterobacteriaceae were identified from Gram-positive and Gram-negative bacteria in bees gut. The Enterobacteriaceae were the most abundant and were represented with 8 bacterial species. The bacterial species identified with MALDI TOF MS Biotyper in bees gut are shown in Table 1.

Table 1 Isolated bacterial strains of Apis mellifera gut

\begin{tabular}{|c|c|}
\hline Family & Bacterial species \\
\hline Lactococcaceae & Lactococcus garvieae \\
\hline Micrococcaceae & Kocuria kristinae \\
\hline \multirow{5}{*}{ Staphylococcaceae } & Staphylococcus capitis \\
\hline & Stapylococcus epidermidis \\
\hline & Staphylococcus haemoliticus \\
\hline & Staphylococcus hominis \\
\hline & Staphylococcus warneri \\
\hline \multirow{8}{*}{ Enterobacteriaceae } & Hafnia alvei \\
\hline & Klebsiella oxytoca \\
\hline & Morganella morganii \\
\hline & Pantoea ananatis \\
\hline & Pantoea agglomerans \\
\hline & Raoultella ornithinolytica \\
\hline & Raoultella planticola \\
\hline & Serratia fonticola \\
\hline
\end{tabular}

The symbiotic microflora of the digestive tract of adult honeybees (Apis mellifera) consist of Gramnegative, Gram-positive and Gram-variable bacteria, moulds, and under some conditions also yeasts. The normal microflora is obtained from consumption of pollen, other food, and through contacts with older bees in the colony. The typical honeybee gut microflora are often consists of Lactobacillus, Bacillus and Bifidobacteria (Kačániová et al., 2004).

Altogether, three bacterial genera were identified among Gram-positive and Gram-negative bacteria and they were Lactococcus, Kocuria, Staphylococcus, Hafnia, Morganella, Pantoea, Raoultella and Serratia. Scores of MALDI-TOF MS Biotyper identification of Lactococcus garvieae ranged from 2.015 to 2.026 , Kocuria kristinae ranged from 2.035 to 2.563 , Staphylococcus capitis ranged from 2.035 to 2.503, Stapylococcus epidermidis ranged from 2.050 to 2.445, Staphylococcus haemoliticus ranged from 2.152 to 2.341, Staphylococcus hominis ranged from 2.150 to 2.345, Staphylococcus warneri ranged from 2.053 to 2.545, Hafnia alvei ranged from 2.296 to 2.563, Morganella morganii from 2.198 to 2.578 , Pantoea ananatis ranged from 2.196 to 2.363 , Pantoea agglomerans ranged from 2.341 to 2.466 , Raoultella ornithinolytica ranged from 2.051 to 2.550 , Raoultella planticola ranged from 2.198 to 2.428 and Serratia fonticola from 2.190 to 2.251 that indicated the reliable identification of bacterial species. 
Taxonomically, $53 \%$ of isolates belonged to Proteobacteria while $40 \%$ to Firmicutes phyla and $7 \%$ to Actinobacterium phyla. All the Gram-negative bacteria isolates belonged to Enterobacteriaceae family (100\%) of Proteobacteria phylum. Gram-positive bacteria belonged to Lactococcaceae, Micrococcaceae, Stapylococcaceae of Actinobacteria and Firmicutes phylum. Unidentified Gramvariable pleomorphic bacteria and bacteria belonging to the genus Bacillus and the family Enterobacteriaceae are the most numerous microbes of the honeybee gut and our results were in agreement with previous findings (Rada eta al., 1997, Kačániová et al., 2004). The intestinal flora of the honey bee is susceptible to various chemotherapeutics and its species composition varies seasonally, therefore the present study provide useful information on the content of gut microflora of honey bee obtained from the hives in Eastern Slovakia.

Altogether, 338 isolates from gut of 50 bees were originated. The Gram-positive and Gram-negative bacterial species recovered exhibited the antimicrobial resistance to the antibiotics. Gram-positive and Gram-negative bacterial showed the more frequently resistance to tigecycline (9.5\%) and amikacin (8.2\%). The resistance to gentamycin (6.5\%) and chloramphenicol (4.1\%) was observed less frequently (Table 2 ).

Table 2 Antibiotic susceptibility testing of bacteria isolated from bees gut

\begin{tabular}{|l|c|c|c|c|}
\hline Antibiotic tested & AMK & GEN & TGC & CM \\
\hline Resistance/Sensitivity & $\mathrm{R} / \mathrm{S}$ & $\mathrm{R} / \mathrm{S}$ & $\mathrm{R} / \mathrm{S}$ & $\mathrm{R} / \mathrm{S}$ \\
\hline Lactococcus garvieae & $0 / 15$ & $0 / 15$ & $0 / 15$ & $0 / 15$ \\
\hline Kocuria kristinae & $5 / 35$ & $2 / 38$ & $3 / 37$ & $0 / 40$ \\
\hline Staphylococcus capitis & $3 / 28$ & $3 / 28$ & $3 / 28$ & $0 / 32$ \\
\hline Stapylococcus epidermidis & $2 / 23$ & $4 / 21$ & $5 / 20$ & $1 / 24$ \\
\hline Staphylococcus haemoliticus & $0 / 20$ & $0 / 20$ & $2 / 18$ & $2 / 18$ \\
\hline Staphylococcus hominis & $1 / 14$ & $0 / 15$ & $2 / 13$ & $3 / 12$ \\
\hline Staphylococcus warneri & $2 / 8$ & $0 / 10$ & $2 / 8$ & $1 / 9$ \\
\hline Hafnia alvei & $2 / 19$ & $2 / 19$ & $5 / 16$ & $2 / 19$ \\
\hline Klebsiella oxytoca & $2 / 30$ & $3 / 29$ & $2 / 30$ & $1 / 31$ \\
\hline Morganella morganii & $0 / 23$ & $1 / 22$ & $3 / 20$ & $1 / 22$ \\
\hline Pantoea ananatis & $4 / 30$ & $2 / 32$ & $3 / 31$ & $1 / 33$ \\
\hline Pantoea agglomerans & $0 / 20$ & $1 / 19$ & $2 / 18$ & $1 / 19$ \\
\hline Raoultella ornithinolytica & $2 / 10$ & $2 / 10$ & $0 / 12$ & $0 / 12$ \\
\hline Raoultella planticola & $2 / 12$ & $1 / 13$ & $0 / 14$ & $1 / 13$ \\
\hline Serratia fonticola & $3 / 22$ & $1 / 24$ & $0 / 25$ & $2 / 23$ \\
\hline
\end{tabular}

AMK - amikacin $(10 \mu \mathrm{g}), \mathrm{GEN}$ - gentamicin $(10 \mu \mathrm{g}), \mathrm{TGC}$ - tigecycline $(10 \mu \mathrm{g}), \mathrm{CM}$ - chloramphenicol $(10 \mu \mathrm{g})$

Several studies have shown that the use of antibiotics causes alterations in the microbiomes of humans and livestock. Therefore, the effects of antibiotic treatment on the honeybee gut microbiome are of major interest alongside with the importance of the gut microbiome in animal, including bees, 
health (Koch and Schmid-Hempel, 2011; Engel et al., 2012; Lee et al., 2015; Schwarz et al., 2016) and in context with the unexplained decline of honeybee colonies (Robinson et al., 2010). This making the studies of composition and the pattern of antimicrobial resistance important for understanding the honey bees nutritional and health-related issues (Potts et al., 2010).

\section{Conclusions}

Bacteria from the family Enterobacteriacea was predominant in gut microflora of Apis mellifera. Resistant Gram-positive and Gram-negative isolates are an issue of concerns with resistance to all the antimicrobials were implicated in the present study. Our study confirms that the gut of Apis mellifera can be a reservoir of pathogenic and resistant to antibiotics bacterial strains. Thus, is essential to continue studies on the composition and the antimicrobial resistance of the gut microflora isolates.

\section{Acknowledgments}

The study was funded by the European Community project No. 26220220180: Building Research Centre "AgroBioTech" and VEGA 1/0411/17.

\section{References}

Ahn, J.H., Hong, I.P., Bok, J.I., Kim, B.Y., Song, J, et al. 2012. Pyrosequencing analysis of the bacterial communities in the guts of honey bees Apis cerana and Apis mellifera in Korea. Journal of Microbiology, vol. 50, p. 735-745. DOI: 10.1007/s12275-012-2188-0

Babendreier, D., Joller, D., Romeis, J., Bigler, F., Widmer, F. 2007. Bacterial community structures in honeybee intestines and their response to two insecticidal proteins. FEMS Microbiological Ecology, vol. 59, p. 600610. DOI: 10.1111/j.1574-6941.2006.00249.x

Batra, L.R., Batra, S.W.T., Bohart, G.E. 1973. The mycoflora of domesticated and wild bees (Apoidea). Mycopathologia et Mycologia Applicata, vol. 49, p. 13-44. DOI: 10.1007/BF02057445

Cox-Foster, D.L., Conlan, S., Holmes, E.C., Palacios, G., Evans, J.D., et al. 2007. A metagenomic survey of microbes in honey bee colony collapse disorder. Science, vol. 318, p. 283-287. DOI: 10.1126/ science.114649.8.

Disayathanoowat, T., Young, J.P.W., Helgason, T., Chantawannakul, P. 2011. T-RFLP analysis of bacterial communities in the midguts of Apis mellifera and Apis cerana honey bees in Thailand. FEMS Micriobiology Ecology, vol. 79, p. 273-281. DOI: 10.1111/j.1574-6941.2011.01216.x

Engel, P., Martinson, V.G., Moran, N.A. 2012. Functional diversity within the simple gut microbiota of the honey bee. Proceedings of the National Academy of Sciences USA, vol. 109, p. 11002-11007. DOI: 10.4161/ gmic. 22517

European Committee on Antimicrobial Susceptibility Testing (EUCAST). Antimicrobial susceptibility testing: Eucast disk diffusion method, version 3.0 from April 2013.

European Committee on Antimicrobial Susceptibility Testing (EUCAST). Breakpoint tables for interpretation of MICs and zone diameters, version 5.0 valid from 2015-01-01.

Evans, J.D., Lopez, D.L. 2004. Bacterial probiotics induce an immune response in the honey bee (Hymenoptera: Apidae). Journal of Economic Entomology, vol. 97, p. 752-756. DOI: 10.1603/0022-0493(2004)097[0752:BPIAIR]2.0.CO;2

Gilliam, M., Prest, D.B., Lorenz, B.J. 1989. Microbiology of pollen and bee bread: taxonomy and enzymology of molds. Apidologie, vol. 20, p. 53-68. DOI: 10.1051/apido:19890106

Kačániová, M., Chlebo, R., Kopernický, M., Trakovická, A. 2004. Microflora of the Honeybee Gastrointestinal Tract. Folia Microbiologica, vol. 49, no. 2, p. 169-171. DOI: 10.1007/BF02931394 
Koch, H., Schmid-Hempel, P. 2011. Socially transmitted gut microbiota protect bumble bees against an intestinal parasite. Proceedings of the National Academy of Sciences USA, vol. 108, p. 19288-19292. DOI: 10.1073/pnas.1110474108

Lee, F.J., Rusch, D.B., Stewart, F.J., Mattila, H.R., Newton, I.L.G. 2015. Saccharide breakdown and fermentation by the honey bee gut microbiome. Environmental Microbiology, vol. 17, p. 796-815. DOI: 10.1111/1462-2920.12526

Martinson, V.G., Danforth, B.N., Minckley, R.L., Rueppell, O., Tingek, S., et al. 2011. A simple and distinctive microbiota associated with honey bees and bumble bees. Molecular Ecology, vol. 20, p. 619-628. DOI: 10.1111/j.1365-294X.2010.04959.x

McFrederick, Q.S., Wcislo, W.T., Taylor, D.R., Ishak, H.D., Dowd, S.E., et al. 2012. Environment or kin: whence do bees obtain acidophilic bacteria? Molecular Ecology, vol. 21, p. 1754-1768. DOI: 10.1111/j.1365-294X.2012.05496.X

McFrederick, Q.S., Cannone, J.J., Gutell, R.R., Kellner, K., Plowes, R.M., et al. 2013. Specificity between Lactobacilli and Hymenopteran Hosts Is the Exception Rather than the Rule. Applied and Environmental Microbiology, vol. 79, p. 1803-1812 DOI: 10.1128/AEM.03681-12

Mohr, K.I., Tebbe, C.C. 2006. Diversity and phylotype consistency of bacteria in the guts of three bee species (Apoidea) at an oilseed rape field. Environmental Microbiology, vol. 8, p. 258-272. DOI: 10.1111/j.1462-2920.2005.00893.x

Moran, N.A., Hansen, A.K., Powell, J.E., Sabree, Z.L. 2012. Distinctive Gut Microbiota of Honey Bees Assessed Using Deep Sampling from Individual Worker Bees. PLoS One, vol, 7, e36393 Available: http://dx.plos. org/10.1371/journal.pone.0036393. DOI: 10.1371/journal.pone.0036393

Potts, S.G., Biesmeijer, J.C., Kremen, C., Neumann, P., Schweiger, O., Kunin, W.E. 2010. Global pollinator declines: trends, impacts and drivers. Trends in Ecology \& Evolution, vol. 25, p. 345-353. DOI: 10.1016/j. tree.2010.01.007

Rada, V., Máchová, M., Huk, J., Marounek, M., Dušková D. 1997. Microflora in the honeybee digestive tract: counts, characteristics and sensitivity to veterinary drugs. Apidologie, vol. 28, p. 357-365. DOI: 10.1051/ apido:19970603

Robinson, C.J., Bohannan, B.J.M., Young, V.B. 2010. From structure to function: the ecology of hostassociated microbial communities. Microbiology and Molecular Biology Review, vol. 74, p. 453-476. DOI: 10.1128/MMBR.00014-10

Rosenberg, E. Zilber-Rosenberg, I. 2011. Symbiosis and development the hologenome concept. Birth Defects Research Part C, vol. 93, p. 56-66 DOI: 10.1002/bdrc.20196

Sabree, Z.L., Hansen, A.K., Moran, N.A. 2012. Independent Studies Using Deep Sequencing Resolve the Same Set of Core Bacterial Species Dominating Gut Communities of Honey Bees. PLoS One 7: e41250 Available: http://dx.plos.org/10.1371/journal.pone.0041250

Singh, R., Levitt, A.L., Rajotte, E.G., Holmes, E.C., Ostiguy, N., et al. 2010. RNA Viruses in Hymenopteran Pollinators: Evidence of Inter-Taxa Virus Transmission via Pollen and Potential Impact on Non-Apis Hymenopteran Species. PLoS One, vol. 5, e14357 Available: http://www.pubmedcentral.nih.gov. DOI: 10.1371/journal.pone.0014357

Schwarz, R., Moran, N.A., Evans, J.D. 2016. Early gut colonizers shape parasite susceptibility and microbiota composition in honey bee workers. Proceedings of the National Academy of Sciences USA, vol. 113, p. 9345-9350. DOI: 10.1073/pnas.1606631113 